\title{
A LA MEMORIA \\ DE MARÍA DEL CARMEN VALVERDE VALDÉS
}

Era un silencio azul poblado de rumores, había una sola estrella colgada de la noche, había una sola boca clamando al infinito, Era un solo lamento.

Hacia la última soledad un único velero blanco parte, dejando atrás la playa de ásperas riberas, amalgama de sal y angustia; dejando atrás su llanto encadenado al asombro de existir.

Un único velero blanco parte hacia la última soledad.

El sollozo inmenso y frágil de la noche se derrama sobre la ausencia.

La playa, encerrada en su propia soledad, se vuelve viento de olvido.

Y más allá, en la orilla de la sombra, ha quedado flotando una sonrisa.

Octubre de 2020

$\infty \infty \infty$

BREVE SEMBLANZA

Siempre alegre, inquieta, inventora, con el ritmo de una abeja afanada por convertir la esencia de la flor en miel, Carmen creó con notable inteligencia una luminosa carrera académica. Con innata generosidad y una vocación bien definida realizó una amplia trayectoria de docencia en distintas instituciones, y de investigación en la UNAM. 
Además de las cualidades señaladas, Carmen se caracterizaba por su dulzura, su solidaridad con todos y su disposición a ayudar a quienes lo necesitaban. Tuve la fortuna de conocer a su mamá, Carmen Valdés, una mujer cálida e inteligente, que legó a Carmen muchas de sus virtudes. Y con su esposo, Arcadio Ojeda y sus hijas Ana Paula y Julia, formó una bella familia.

$\infty \infty \infty$

Hacia 1983, al empezar mi curso de Civilización Maya, una lucecita brilló entre el nutrido grupo de alumnos, y siguió brillando durante todo el curso. Era Carmen; participó muy activamente en las clases, como era ella. De ahí en adelante, se fascinó con los mayas, que la atraparon para siempre y se interesó principalmente por la religión. Tenía la sensibilidad y la inteligencia para ello. Muy pronto se convirtió en mi ayudante y se internó en la docencia en la UNAM, impartiendo algunas de las clases, pero ambas asistíamos a todas las sesiones, apoyándome ella con varias actividades relacionadas con el curso, heredado del doctor Alberto Ruz Lhuillier: "La Civilización Maya".

En 1985 hizo su servicio social participando en la organización del Primer Coloquio Internacional de Mayistas del Centro de Estudios Mayas. Ahí se vinculó con todos los miembros del centro. Su labor fue esencial, pues en esa participación desplegó sus dotes organizativas, sus iniciativas, su pasión por los mayas. Y en todos los congresos que siguieron, hasta el último, en Chetumal, su apoyo y sus iniciativas fueron esenciales, con esa vitalidad y esa capacidad de solucionar problemas. iEra difícil seguir su ritmo!

Con la misma vocación docente me apoyó en la coordinación del diplomado Teoría e Historia de las Religiones, que después de varios años pasó a sus manos, al lado de Mauricio Ruiz Velasco. Del diplomado surgieron dos libros con trabajos de los alumnos, que ella coordinó. Asimismo, creó el Plan de Estudios del diplomado Análisis del mito, participó activamente en otros planes de estudios y su labor fue esencial para la consolidación de la Maestría en Docencia en Educación Media Superior (MADEms).

Asistió a muchos cursos de actualización que enriquecieron su formación académica, y sembró sus conocimientos en cientos de alumnos en innumerables cursos y en asistentes a sus conferencias y ponencias en congresos, nacionales e internacionales. Como todos sabemos, la labor docente implica investigación y actualización, lo cual es parte de la responsabilidad esencial de un maestro, de modo que no es fácil un trabajo de docencia tan intenso.

En cuanto a su participación directiva, coordinó el Centro de Estudios Mayas y el Posgrado en Estudios Mesoamericanos, haciendo las modificaciones necesarias al plan de estudios, y enriqueciendo las actividades del centro. Cumplió con esos cargos con cordialidad, pero con energía y firmeza. Fue muchas veces directora de tesis de licenciatura y posgrado, cotutora y sinodal, y se hizo cargo del Seminario de Cultura Maya, también heredado del doctor Ruz, cuando no pude ya impartirlo.

Desde que ingresó al CEM como investigadora formamos, con Laura Sotelo y Martha Ilia Nájera, un área dedicada a la religión. A ella le interesaban principalmente los símbolos como lo muestra su tesis de licenciatura sobre el símbolo de la cruz en la religión maya. 
Como grupo, participamos en varios de los congresos de mayistas con simposios y conferencias en esa área.

En los últimos tiempos realizamos con varios participantes, integrando a la Universidad de Yucatán y a la Universidad de Oriente de Valladolid, el proyecto "Plantas sagradas de los mayas", cuya responsable fue Laura Sotelo, y Carmen y yo, corresponsables. En este proyecto ella armó y dirigió, reuniendo a todos los participantes, el Seminario de Plantas Sagradas, que mejoró los trabajos presentados, y colaboró ampliamente en la página web. Le dio gusto conocer, ya impreso, nuestro primer libro: El poder de las plantas sagradas en el universo maya (noviembre de 2019). El segundo lo coordinaba ella, labor que continuó Laura y que pronto será publicado; en él se incluye un capítulo suyo, que fue su ponencia presentada en Chetumal, en el simposio Plantas sagradas de los mayas, que ella organizó.

En cuanto a su obra escrita, además de múltiples artículos y capítulos en libros, sus libros de autoría original fueron: Chiapa de Corzo. Épocas Prehispánica y Colonial, una monografía. Balam, el jaguar a través de los tiempos y los espacios del universo maya, excelente investigación que fue su tesis de doctorado; en este trabajo aúna a la investigación profunda sobre el simbolismo del jaguar entre los mayas antiguos, su pasión por los animales, logrando una visión excelente sobre ese gran felino. Symbolon (Serie Cuadernos del CEM). Los mayas (Conaculta) y en colaboración con Arcadio Ojeda, El jaguar, señor del inicio y del fin del mundo.

En el Centro de Estudios Mayas formó parte y dirigió algunos proyectos de investigación colectivos, como "Chichén Itzá". De los proyectos, simposios y conferencias en los que participó surgieron libros colectivos que ella coordinó, como Continuidad, cambios y rupturas en la tradición maya, Guía de arquitectura y paisaje mayas, Imágenes precolombinas y La noción de vida en Mesoamérica.

Y Carmen, en búsqueda de otros derroteros que no fueran lo prehispánico y lo colonial, se internó en la investigación sobre las guerras con el proyecto "Símbolos religiosos de las rebeliones indígenas en el área maya durante el siglo xix", como resultado del cual escribió varios trabajos: conferencias, artículos, capítulos y ponencias. Uno de ellos fue "Tiempos de cambio y de permanencia. Tiempos de resistencia", en el libro que recoge un simposio que presentamos en Atenas en uno de los Congresos Internacionales de Filosofía: El tiempo de los dioses-tiempo. Concepciones de Mesomérica.

$$
\infty \infty \infty
$$

Esa luz que nos iluminó por décadas con su personalidad y su dinamismo excepcionales, se apagó el 4 de octubre de 2020, por designio de la vida, pero nos dejó un rastro de estrellas que seguirán brillando mientras la recordemos con gratitud y amor.

Mercedes de la Garza

Centro de Estudios Mayas, Instituto de Investigaciones Filológicas, unAm 